Institutional Arrangements and Firm Behavior: The Case of Common Forests in Sweden Author(s): Jerry Blomberg and Mats Nilsson

Reviewed work(s):

Source: Journal of Economic Issues, Vol. 31, No. 2 (Jun., 1997), pp. 401-408

Published by: Association for Evolutionary Economics

Stable URL: http://www.jstor.org/stable/4227189

Accessed: 19/04/2012 12:48

Your use of the JSTOR archive indicates your acceptance of the Terms \& Conditions of Use, available at http://www.jstor.org/page/info/about/policies/terms.jsp

JSTOR is a not-for-profit service that helps scholars, researchers, and students discover, use, and build upon a wide range of content in a trusted digital archive. We use information technology and tools to increase productivity and facilitate new forms of scholarship. For more information about JSTOR, please contact support@jstor.org. 


\title{
Institutional Arrangements and Firm Behavior: The Case of Common Forests in Sweden
}

\author{
Jerry Blomberg \\ and \\ Mats Nilsson
}

Increasing environmental degradation and the threat of running down the stock of important natural resources have led to a growing interest in how and to what extent different property rights regimes affect natural resource management. Since that part of nature recognized as resources, whether renewable or finite, is always more or less scarce, there has always been competition over the benefits and services that such resources provide. To hinder overuse, human societies, regardless of culture, have developed different institutional arrangements that address the problem of who will have the property rights. These arrangements could be viewed as a system of rules and norms that limits individual use of the resource. Given that there is a need for a system of rights to use, the challenge then becomes that of finding a system that allows appropriation of the resource in the most sustainable fashion possible. Different property rights systems give different sets of incentives that will affect the output decision and hence sustainability. The purpose of this paper is to investigate to what extent special features within common forests have affected output decisions.

\section{A Brief History of the Common Forests of Sweden}

Common forests have a very long history in Sweden. In the beginning of the sixteenth century, the property rights in the north of Sweden were unclear. A process

The authors are Lecturers of Economics, Lulea University of Technology. This paper was presented at the annual meeting of the Association for Evolutionary Economics, New Orleans, Louisiana, January 46, 1997. 
was therefore begun whereby the rights of the Crown (by far the largest landholder in the north) and the individual homesteads and settlements were clarified. Because of the poor agricultural possibilities in these areas, the income of the farmers had to be supplemented. To achieve better conditions for the colonizing farmers, the Crown supported them in two ways. First, property rights to parts of the Crown forests were transferred directly to especially weak homesteads. Second, homesteads were given a right to harvest timber and fuelwood from parts of the remaining Crown forests. The size of the harvest the farmers had a right to was determined by the hide ${ }^{1}$ and the site quality of the forest. This right was the foundation of what later became the common forests.

During the second half of the nineteenth century, three factors led to pressure to formalize the rights of the farmers. First, there was a need to hinder what was believed to be a threatening overexploitation of the forest lands in Sweden [Governmental report, Ds Jo 1983:15, s 59]. This was caused by an increased commercial value of timber at that time and the related growth of the sawmill industry. ${ }^{2}$ It is thought that this development was endangering the original purpose of providing support for farming, and to maintain this purpose, the state tried to protect the common forests from outside economic interests. Second, the industrial society was in need of a steady and increasing flow of forest raw materials. This could only be achieved by creating larger and more productive units of forest lands. Third, the Crown wanted to guarantee that the profits from forestry went back to the local community to support public aims such as road building, electrification, schools, and social security.

Between 1861 and 1918, 24 common forests were created in the counties of Dalarna, Västerbotten, and Norrbotten. This meant changing the ownership from the Crown to the de facto users of these forests. In those units, property rights were not individual, but common among those homestead owners utilizing the resource prior to the formalization. From 1903 onward, several attempts were made to create uniform legislation for the different common forests, but not until 1938 did the Swedish parliament pass legislation. During the intervening time, a considerable amount of government control and involvement in the management of the common forests took place. In the 1938 legislation, the management and control was to a substantial degree entrusted to the proprietors. The legislators reasoned that the owners already possessed the common forest with rights similar to that of ownership. However, due to the great economic significance of the forests, the rights of the owners were still regulated in several ways. The common forests were to be harvested sustainably and were under no circumstances to be partitioned among the proprietors. The supervision of the forests was entrusted to the county forest boards. Only minor revisions have been made since the 1938 legislation. 


\section{The Structure and Governance of Swedish Common Property Forests}

Swedish law constitutes the framework in which the common forests have to be managed. ${ }^{3}$ The law regulates the purpose of the common and how it should be managed; sets up guidelines for the common's own internal regulation; forms the relationship between individuals, co-owner property, and the common; stipulates rules for acquisition and disposal of land; and regulates the use of surplus from the common. ${ }^{4}$ Considering the management of the common, the intentions of the law are clear. The common forests should be managed to give the highest return possible. A second intention is that the return should, if possible, be evenly distributed over time. $^{5}$

The property right is connected to a judicial entity, i.e., the homestead, and not to individuals. The homestead is in turn owned by individuals or other judicial entities such as forest corporations. Over time, the ownership of the homesteads and the rights connected to them have been complicated by an increasing share of absentee proprietors who do not, in effect, count on contributions from the common forest for their livelihood (see Table 1). Forest corporations constitute another important category of owners, controlling in some areas up to 80 percent of the "shares" in the

\section{Table 1. Price-Cost Margin-Output Relationship}

Vertical Negative Positive Row Total

$\%$ of Absentee Owners

$0-20$

$21-40$

41 -

Column Total

$\begin{array}{rrrr}1 & 7 & 4 & 12 \\ 1 & 3 & 2 & 5 \\ 1 & 5 & 1 & 7 \\ 3 & 15 & 6 & 24\end{array}$

\% Owned by Forest Corporation

$0-20$

$21-40$

$41-$

Column Total
3

0

0

3

Payment Vehicle
Direct Dividend

Subsidy

Column Total

1

2

3

Ownership of Business Enterprises

Yes

No

Column Total
2

3

\section{8}

4

3

15
12

5

7

24 
common forest. ${ }^{6}$ The common forest could also partially own "itself." In some instances, when a right-holding homestead has been sold, the common has bought it, incorporating it into itself. The Karesuando common provides an interesting exception. It is fully owned by the municipality of Kiruna. Therefore, it is viewed not as the property of the residents of Karesuando, but of all residents living in Kiruna. It follows that this common is governed by the politicians running the Kiruna municipality.

Some of the common forests own businesses, either partially or fully. These enterprises range from sawmills to hydropower plants and often represent substantial values. ${ }^{7}$ In many cases, these businesses are not commercially run, but fulfill other purposes. For example, sawmills, may be owned by members of the local community where the common is located, and members can utilize it at a low cost.

The size of administration varies according to the respective policy adopted by different commons. Even though some of the commons have decreased their staff and capital stock, many hold relatively large numbers of employees and machinery. Local employment is the leading aim of this policy. In the common forests with large staffs, there is incentive to keep the employees at work by annual logging activities, while those with small or no staffs are able to sell their output as standing timber [Carlsson 1995].

The board of the individual common decides how the surplus from the common should be distributed among the proprietors. It should be noted that one of the purposes of these funds is to even out the surplus over the years. There are two methods used for distributing the surplus. First, the surplus is distributed as a direct dividend without any services in return demanded from the co-owners. Second, the surplus is distributed to those proprietors who apply for grants from the common. These proprietors should do some service in return, for example, forest regeneration.

\section{The Institutional Setting and the Outcome}

The questions examined in this study are what behavioral assumptions best describe the actions of the managers and co-owners of the common forests in Sweden? How does this behavior affect output, and hence, in a wider sense, sustainability? To understand cutting behavior is especially interesting considering that the common forests in the industrialized age have to compete with other roundwood suppliers in the marketplace. It could therefore be argued that they are likely to have behaved like any other roundwood supplier, i.e., increasing output when the price-cost margin (PCM) increases. Such behavior would be contrary to the original intentions of the Swedish common forests.

Earlier studies of the Swedish roundwood market have shown that private forest owners act like profit maximizers, that is, when price rises, ceteris paribus, quantity 
harvested increases [e.g., Brännlund 1988]. There are, however, no similar studies of common forest management. Given the institutional setting and history, it could as well be argued that the common management would try to reach a target revenue, rather than maximize profit. That is, when price rises, ceteris paribus, quantity harvested would decrease.

Our study is of 24 common forests. ${ }^{8}$ The time period considered covers the years 1980-93, which contains both recessions and a boom period. It would be preferable to have longer time series; these are, however, not available because of the difficulty of obtaining disaggregated, owner-specific data.

Using the $\mathrm{PCM}^{9}$ and the commons annually harvested quantity, only 6 out of 24 has a positively sloped PCM-output relationship. ${ }^{10}$ In some of these cases, the positive correlation is extremely weak. Fifteen of the common forests exhibit a negatively sloped "supply curve." Three of the cases show a constant quantity harvested over the studied period, thereby denying the proposed explanations.

Interestingly enough, data in Table 1 show that five out of six of the commons exhibiting a positive output-PCM relationship own subsidiaries. This could indicate the importance of external effects that would come from management of the subsidiaries that would be acting in a more competitive environment. This argument is strongly weakened by the conventional wisdom that many of these enterprises are not commercially run. Further weakening this argument is the fact that there are three commons-owning corporations with negative output-PCM relationship. However, what is clear is that virtually all commons lacking subsidiaries do react by decreasing output when the PCM increases. A possible explanation might be that the commons without subsidiaries are "free" from the burden of subsidizing unsuccessful business ventures. ${ }^{11}$

An odd result seen in Table 1 is that of the common forests using direct dividend as a method for distributing the surplus among the owners, all but one responds negatively on a PCM increase. Intuitively, one would expect that if an owner gets his/her share of the surplus without any services in return, he/she would demand higher returns when the PCM increases, as, e.g., the stock market. This could indicate a satisficing behavior in accordance with specific institutional constraints, i.e., those goals and internal rules of the common that have developed over time. As described above, one of the goals specified in the law is that the commons should achieve the highest possible but even return over time.

Absentee ownership of forest resources has been discussed in Sweden over the past 20 years. Supposedly, owners not living on the forest estate would harvest at a lower rate than other categories of owners. This has been rejected in the case of private forest owners [Lönnstedt 1977]. We find using Table 1 that in the case of Swedish common forests, the larger the proportion of absentee owners becomes, the more likely it is that the common forest will react negatively on a PCM increase. This could possibly indicate that absentee owners with other sources of income than 
forestry have little incentive to try to change management of the common forests toward a more profit-maximizing behavior, i.e., the income from the common forests is "residual" to the owners.

It could be anticipated that some of the commons that are largely owned by forest corporations would act in a more business-like manner, i.e., profit maximize. Nevertheless, no clear relationship could be found between the share of corporate ownership and the quantity harvested (see Table 1). How could this be explained? First, it can be assumed that by interfering, the companies stand the risk of loosing goodwill, which might endanger the long-term relationship with the common forests. ${ }^{12}$ Second, remembering that one of the original aims of the common movement was to limit corporate influence, many commons have limited the voting rights for large owners. Also, the commons have in many cases limited the right to subsidies or dividends. Thus, this directly constrains the forest corporation influence in the common forests management decisions [Carlsson 1995].

\section{Conclusions}

What behavioral assumption best describes the actions of the managers and coowners of the common forests in Sweden? This is the question this paper tries to explore. In doing so, we have described the historical roots and development of the common forests. We have tried to highlight the differences between common forests in an attempt to explain how forestry resources are used by this particular group of owners. Historically, the purpose of the common forests has been long-term development of the region through sustainable forest management. We contrast this with two alternative views. First, the common forest can be viewed as any profit-maximizing entity in society. Second, the common forests' behavior could best be explained by assuming that they act upon a target revenue. Casual evidence rejects the profit-maximizing hypothesis in most of the 24 cases studied. The target revenue assumption could be supported by the evidence that most of the common forests seem to harvest less when the PCM increases. ${ }^{13}$ This indicates a possibly sustainable management. We have tried to explain this behavior by comparing four variables: payment vehicle, share of corporate ownership of the common, share of absentee owners, and the ownership of companies by the common. The findings indicate that most variables either give inconclusive or counterintuitive results. The ownership of enterprises by the common is the only variable having any possible, although weak, ramification. It seems that those commons without subsidiaries are freer to choose whatever behavior they want. All but one reacts negatively on a PCM increase, indicating a target revenue behavior. One caveat that could possibly reject both the profit-maximizing and the target revenue assumptions is the fact that some commons have developed a local policy of keeping a certain work force, i.e., maintaining local employment. This would lead to a certain required harvest each year to keep the 
work force employed, i.e., a target output behavior. This study is explorative and descriptive, leaving many further questions to be answered. Fruitful developments would be to incorporate the effects of subsidies and taxes into the study. It would be interesting to further explore the interaction between the common and the buyers of roundwood, with an emphasis on the "design" of the long-term relationship. A fuller understanding of this might render new conclusions and new sets of hypotheses.

\section{Notes}

1. The hide was originally determined by the hay-producing capacity of the cultivated lands of each homestead.

2. From 1850 to 1870 , the export of boards and planks from Söderhamn in the south to Haparanda in the north increased tenfold.

3. For a thorough treatment of the law, see Anon [Ds Jo 1983:15].

4. The law also stipulates that there should be an assembly, board, and an administration. The board is elected by the assembly, which is held twice a year, though there are exceptions to this rule. All operative decisions, such as the economy and day-to-day management, are the sole responsibility of the board. This task is often delegated to an administrator with a degree in forestry. The common forests are managed in accordance with 10-year thrift plans, following the general guidelines of the county forestry board. The common forest is also under the supervision of the county council.

5. See Anon $D s J o[1983: 15,19,178]$ for a historical statement of this goal.

6. This, at first glance, is a peculiar fact considering that one of the aims with the common forests was to inhibit the influence of the forest corporations and is due to the fact that many homesteads already were owned by corporations in the beginning of the twentieth century when the movement to protect the common forests by legislation started.

7. For example, Älvdalen's common forest partially owns two hydropower plants in the Österdal river, from which they receive 7 MSEK in revenues annually.

8. There are other types of common forests in Sweden, but here we only study those that came about through the historical process described.

9. This has been calculated by using weighted prices of roundwood in the market and average cutting costs.

10. A naive application of this kind may encounter difficulties. If we do have simultaneous movements in supply and demand, in a "Marshallian" sense, our "test" is incomplete in the best of worlds and erroneous in the worst case.

11. Lars Carlsson [1995] has found that many common forests have been involved in various degrees of vertical integration. In many cases, the motives have been other than business profits. Many of these enterprises have failed, whether the purpose has been commercial or not.

12. The common forests of southern Sweden often have formalized long-term delivery contracts with forest corporations, while in the north, roundwood is usually sold as standing timber (stumpage).

13. Other types of forest owners-private, corporate and the state-react by increasing the harvest when PCM increases. 


\section{References}

Anonymous. Ds Jo 1983:15 Common Property Forests. Governmental report, Stockholm: Liber, 1983 (in Swedish).

Brännlund, Runar. The Swedish Roundwood Market-An Econometric Analysis. Ph.D. diss., Umeå: Swedish University of Agricultural Science, Department of Forest Economics, Report no. 82, 1988.

Carlsson, Lars. Common Property Forests in Sweden. Luleå: University of Luleå, Department of Political Sciencè, Research Report no. 22, 1995 (in Swedish).

. "Commons and Commoners." Paper presented at the conference Institutional Analysis and Development, University of Indiana, Bloomington, 1996.

Eggertsson, Thrainn. Economic Behavior and Institutions. Cambridge: Cambridge University Press, 1990.

Johansson, P.O., and K.G. Löfgren. The Economics of Forestry and Natural Resources. Oxford: Basil Blackwell, 1985.

Lönnstedt, Lars. Why Does the Private Forest Owner Cut? Umeå: Swedish University of Agricultural Science, Department of Forest Economics, Report no. 23, 1977 (in Swedish). 